Centre for Economics And Management IFP School

\title{
Capital Budgeting, Investment Project Valuation and Financing Mix: Methodological Proposals
}

Denis BABUSIAUX Axel PIERRU

April 2000

Cahiers du CEG - n 36

Série Recherche

ÉCOLE DU PÉTROLE ET DES MOTEURS

Centre Économie et Gestion

228-232, avenue Napoléon Bonaparte

92852 RUEIL-MALMAISON CEDEX

téléphone : 0147526687 - télécopieur : 0147527066 
This paper will be presented at the $26^{\text {th }}$ Meeting of the EURO Working Group on Financial Modelling which will be held at the Norwegian University of Science and Technology in Trondheim (Norway) on May 4-6, 2000.

\author{
denis.babusiaux@ifp.fr \\ axel.pierru@ifp.fr
}

La collection "Cahiers du CEG" est un recueil de présentations de travaux réalisés au Centre Économie et Gestion de l'École du Pétrole et des Moteurs, Institut Français du Pétrole, travaux de recherche ou notes de synthèse. Elle a été mise en place pour permettre la diffusion de ces travaux, parfois sous une forme encore provisoire, afin de susciter des échanges de points de vue sur les sujets abordés.

Les opinions émises dans les textes publiés dans cette collection doivent être considérées comme propres à leurs auteurs et ne reflètent pas nécessairement le point de vue de l'École du Pétrole et des Moteurs ou de l'IFP.

Pour toute information complémentaire, prière de contacter :

Valérie SAINT-ANTONIN tél. : 0147526687

valerie.saint-antonin@ifp.fr

The "Cahiers du CEG" is a collection of articles carried out at the Center for Economics and Management of the IFP School, Institut Français du Pétrole. It is designed to promote an exchange of ideas on the topics covered.

The opinions expressed are the sole responsability of the author(s) and do not necessarily reflect the views of the IFP School or IFP.

For any additional information, please contact :

Valérie SAINT-ANTONIN Phone : + 33147526687

valerie.saint-antonin@ifp.fr 


\begin{abstract}
The results presented here are part of research work originally based on the problem concerning the valuation of investment projects subject to specific fiscal rules, such as those encountered in the upstream oil industry. More precisely, the first question addressed was how to determine the economic value of an investment project partly financed by borrowing, when the revenue from the project is subject to a different tax rate from the one used to calculate the discount rate, and when the loan allocated to the project is different from the one corresponding to the target debt ratio defined by the company for this type of projects. We propose a method which is, in fact, more general in scope. It is presented in the first part of this article and corresponds to the adaptation of classic ATWACC calculations. A simple answer is to add each year, to the project cash flow, an after tax loan cost differential (negative or positive). The formulation adopted ("generalized ATWACC method") is independent of any consideration related to debt ratios. The second question addressed here is the use of the Arditti-Levy (BTWACC) method, the one most commonly used in the Exploration-Production branch of the oil industry. While the method is appropriate to deal with for complex specific tax rates, it needs to be adjusted if the company allocates to a project a loan representing proportionally more (or less) than the fraction corresponding to its consolidated debt ratio. A suitable approach is developed here. However the formulation, by further complicating a method which in any case cannot be used without precaution, does not possess the simplicity of that of the generalized ATWACC method, and the latter should therefore be preferred in all situations.
\end{abstract}




\section{Introduction}

In companies, the investment decision process has very often to go through deterministic profitability calculations made for different scenarios, each leading to a specific stream of cash flows (whatever may be the final approach selected to take risk into account). Various methods, with well established consistency (Boudreaux and Long [1979], Chambers et al. [1982], Babusiaux [1990]) can be used to analyze investment projects. The most widely used in textbooks and in practice alike corresponds to ATWACC profitability calculations. The discount rate used is an After Tax Weighted Average Cost of Capital (ATWACC). In the petroleum upstream sector (crude oil exploration and production), the Arditti-Levy (or "shadow interest" or BTWACC)) method is the more commonly used. The corresponding discount rate is in fact defined as a Before Tax Weighted Average Cost of Capital (BTWACC), and is hence independent of the tax rate. This approach therefore appears more appropriate to the upstream oil industry, which is subject to very different tax specificities.

One aim of this article is to qualify this observation and, in the first part, to show that the ATWACC method can be used to analyze a project's profitability when the earnings of the project are subject to a different tax rate from the one used to calculate the discount rate. The very simple formulation proposed ("generalized ATWACC method") offers a considerable advantage in that it is valid regardless of the characteristics of the loan used to finance the project, particularly the loan amount. In certain cases, companies may be encouraged to allocate to their projects loans representing more (or less) than the fraction corresponding to the debt ratio defined for projects belonging to the same class of risk. In general, however, they have to respect this target debt ratio on a company-wide basis. The method presented accounts for this necessity.

The second part is devoted to an approach adapted to the use of the BTWACC method, consistent with the method presented in the first part. But the formulation presented does not have the simplicity of the one corresponding to the "generalized ATWACC method", and thereby tends to further complicate a method which, in any case, cannot be used without precaution.

As a result of the discussion in the last part, relative to advantages and disadvantages of the two approaches, we therefore propose the use of the first approach as main reference method in all cases.

The more theoretical results of the research work carried out on the problem examined here are developed elsewhere (Pierru and Babusiaux, [2000]). They show that the different capital budgeting methods (ATWACC, Arditti-Levy, Equity Residual, Adjusted Present Value ...) can be derived from a unique formulation. This ensures immediate proof of their consistency and allows generalization of some results and formulas, including that of Modigliani and Miller. 


\section{Use of ATWACC calculations in the presence of different tax rates}

\subsection{Presentation of the problem}

Let us consider a company of sufficient size to assume that it resorts to new borrowings every year. It is subject to income tax. To examine its investment projects of a given class of risk with the help of ATWACC calculations, it uses a discount rate $i$ (in current value):

$i=w(1-t) r+(1-w) c$

where $w$ : target debt ratio for the set of projects with the same class of risk (for instance oil field development projects)

$t$ : corporate tax rate

$r:$ loan interest rate

$c$ : cost of equity

We shall subsequently consider the case in which some of these quantities vary with time. Let $i_{n}, w_{n}, t_{n}, r_{n}$ and $c_{n}$ denote their respective values in year $n$.

The company analyzes the profitability of an investment project to be carried out in a foreign country with a different tax rate or, in general, in which income is taxed at a rate (or rates) different from rate $t$. We shall restrict ourselves to a case in which there is no tax consolidation, or to fairly common equivalent cases ${ }^{1}$ in the field of oil and gas exploration and production. We also assume that the project can be financed partly by borrowing and that the corresponding interest expense is deductible from the project's taxable income.

\subsection{Proposed general approach ("Generalized ATWACC method")}

Let $P^{\prime}$ be the loan contracted to carry out the project the after tax cost of which being different (for instance because of a distinct tax regime) from the usual corporate one. Regardless of the amount and debt ratio $w$ fixed by the company, loan $P^{\prime}$ can be considered to substitute for a loan $\pi$ which would have been negotiated by the central departments of the company. Loan $\pi$, in the same amount as loan $P^{\prime}$, would be repaid over the same period and with the same repayment schedule. In other words, the capital repayment schedules would be identical. This assumption, while it may seem theoretical, reflects the fact that loan $\pi$ must lead each year to the same total debt ratio as loan $P^{\prime}$ (assumption commonly used for economic calculation with a debt ratio fixed a priori).

Remark: In practice, for the substitute loan $\pi$, this can lead to unusual repayment arrangements that could be considered unrealistic. In fact, the substitution may concern not a single loan but - if the repayment arrangements cannot be adjusted to comply with the ratio - different loans negotiated over the study period, of which the amounts are precisely adjusted in order to maintain the fixed debt ratio. To consider loan $\pi$ is accordingly equivalent to considering these different variations.

Let us denote:

$r^{\prime}$ : interest rate of loan $P^{\prime}$ associated with the project,

\footnotetext{
${ }^{1}$ For example, if the local tax rate is heavier than the French tax rate for a French company applying the rules of the worldconsolidated taxation regime ( a form of the worldwide approach).
} 
$B_{n}^{\prime}$ : borrowed capital remaining due at the end of year $n$,

$\theta_{n}:$ tax rate applicable to project income in year $n$.

The interest expense associated with loan $\mathrm{P}^{\prime}$ in year $n$, amounting to $r^{\prime} B_{n-1}^{\prime}$, generates tax savings $\theta_{n} r^{\prime} B_{n-1}^{\prime}$. The after tax cost of the loan is:

$\hat{r}_{n}^{\prime}=\left(1-\theta_{n}\right) r^{\prime}$

(note that if the financing charges are not deductible from taxable income, it suffices to use: $\left.\theta_{n}=0\right)$

The after tax cost of the interest expense amounts to:

$\hat{r}_{n}^{\prime} B_{n-1}=\left(1-\theta_{n}\right) r^{\prime} B_{n-1}^{\prime}$

Similarly, the after tax cost of interest associated with loan $\pi$ in year $n$ would have been:

$$
\hat{r} B_{n-1}^{\prime}=(1-t) r B_{n-1}^{\prime}
$$

The difference between these two terms must be credited to the project. Let $F_{n}$ be the after tax operating cash flow generated by the project (not including any loan related item). The cash flow $G_{n}$ allocated in year $n$ to the project is:

$$
G_{n}=F_{n}+\left[(1-t) r-\left(1-\theta_{n}\right) r^{\prime}\right] B_{n-1}^{\prime}=F_{n}+\left(\hat{r}-\hat{r}_{n}^{\prime}\right) B_{n-1}^{\prime}
$$

The Net Present Value of the project is thus written (1):

$$
\mathrm{NPV}=\sum_{n=0}^{N} \frac{G_{n}}{(1+i)^{n}}=\sum_{n=0}^{N} \frac{F_{n}+\left[(1-t) r-\left(1-\theta_{n}\right) r^{\prime}\right] B_{n-1}^{\prime}}{(1+i)^{n}}=\sum_{n=0}^{N} \frac{F_{n}+\left(\hat{r}-\hat{r}_{n}^{\prime}\right) B_{n-1}^{\prime}}{(1+i)^{n}}
$$

Remark 1: The foregoing procedure is a generalization of the one proposed by Babusiaux (1990) to analyze the profitability of a project in allowing to borrow at a preferential rate $r^{\prime} \neq r$, the gain to be credited to the project in year $n$ being non taxable $\left(r-r^{\prime}\right) B_{n-1}^{\prime}$, or after tax (1-t) $\left(r-r^{\prime}\right) B_{n-1}^{\prime}$.

Remark 2: The definition of loan $\pi$ can give rise to different interpretations. For example, in case of preferential rate loans, some authors suggest considering loan $\pi$ as repayable in constant monthly (quarterly or annual) installments if loan $P^{\prime}$ is thus defined. This assumption may appear more natural than the one we have used above, but it does not (strictly) conform to the one which represents the main theoretical reference, i.e. an unchanged debt ratio when substituting one loan for another.

\subsection{Projects with the same debt ratio as the company target debt ratio}

In the next paragraph (1.4) we shall analyze a project financed by means of a loan such that the project has the same debt ratio as the target debt ratio, throughout the life of the project. We shall conventionally consider a debt ratio defined in relation to the value of the project. Before considering a project subject to a different tax rate from the one applicable to the company, let us briefly recall, in general, how such a debt ratio can be defined. 
To avoid using the above notation, whatever be the method used, let $\varphi_{n}$ be the cash flow associated with the project in year $n, j$ being the relevant discount rate.

In any year $n$, the value of the project $V_{n}$ is the sum of its discounted future cash flows:

$V_{n}=\sum_{k=n+1}^{N} \frac{\varphi_{k}}{(1+j)^{k-n}}$

It can also be defined from the recurrence equation:

$V_{n}=\frac{V_{n+1}+\varphi_{n+1}}{1+j}$

where $V_{N}=0$

If $B_{n}$ is the loan amount remaining due in year $n$, the assumption concerning the project debt ratio (equal to the target debt ratio, $w$ ) is written:

$$
B_{n}=w V_{n}
$$

In particular in year 0 :

$B_{0}=w V_{0}=w \sum_{k=1}^{N} \frac{\varphi_{k}}{(1+j)^{k}}$

If the cash flow of year 0 only corresponds to an investment expenditure denoted $I_{0}$ :

$B_{0}=w V_{0}=w\left(I_{0}+N P V\right)$

In other words, the debt ratio is not defined in relation to the investment cost (ex post facto historic cost), but by reference to the theoretical economic value of the project, i.e. the present value of its future flows.

\subsection{Projects subject to specific tax rates and having the same debt ratio as the company}

Let us return to the study of a project subject to a different tax rate from the one generally applied to the company. Let us assume that this project is partly financed by borrowing so that its debt ratio, as above, is constantly equal to the target debt ratio $w$. We shall show that the Net Present Value of the project, which is equal to the sum of the cash flows $G_{n}$ discounted at rate $i$, is also equal to the sum of the operating cash flows $F_{n}$ discounted at the rate(s) corresponding to the after tax average cost(s) of the capital invested in the project.

To start by presenting a simple formula, let us consider the case in which the tax rate $\theta$ on income from the project is constant over time.

The after tax weighted average cost of capital invested in the project is written: 
$y=w(1-\theta) r^{\prime}+(1-w) c$

and the announced formula:

$$
\sum_{n=0}^{N} \frac{G_{n}}{(1+i)^{n}}=\sum_{n=0}^{N} \frac{F_{n}+\left[(1-t) r-(1-\theta) r^{\prime}\right] B_{n-1}}{(1+i)^{n}}=\sum_{n=0}^{N} \frac{F_{n}}{\left(1+w(1-\theta) r^{\prime}+(1-w) c\right)^{n}}=\sum_{n=0}^{N} \frac{F_{n}}{(1+y)^{n}}
$$

As a rule, the value of the project $V_{n}$ in any year $n$ can be calculated in two equivalent ways:

$$
V_{n}=\sum_{k=n+1}^{N} \frac{G_{k}}{(1+i)^{k-n}}=\sum_{k=n+1}^{N} \frac{F_{n}}{(1+y)^{k-n}}
$$

This result is intuitive and could have been assumed a priori. It shows that the NPV, and in general, the economic value of the project $V_{n}$ in any year $n$, can be calculated by discounting the operating cash flows at a rate equal to the after tax average cost of the specific financing of the project.

We refer to this property elsewhere (Pierru and Babusiaux [2000]) to infer a theoretical result: since the project NPV is independent of the rate $t$, any value can be assigned to this parameter. Each of the conventional methods (Arditti-Levy, equity, Adjusted Present Value, Z-flow) corresponds to a specific value of $t$, offering very simple evidence of their consistency.

If one of the parameters, such as the project tax rate $\theta$, or several of the parameters, vary over time, by introducing a subscript representing the year concerned, the formula becomes:

$$
V_{n}=\sum_{k=n+1}^{N} \frac{F_{k}+\left[\left(1-t_{k}\right) r_{k}-\left(1-\theta_{k}\right) r_{k}^{\prime}\right] B_{k-1}}{\prod_{m=n+1}^{k}\left(1+i_{m}\right)}=\sum_{k=n+1}^{N} \frac{F_{k}}{\prod_{m=n+1}^{k}\left(1+y_{m}\right)}
$$

with:

$$
\begin{aligned}
& i_{m}=w_{m} r_{m}\left(1-t_{m}\right)+\left(1-w_{m}\right) c_{m} \\
& y_{m}=w_{m} r_{m}^{\prime}\left(1-\theta_{m}\right)+\left(1-w_{m}\right) c_{m} \\
& V_{N}=0
\end{aligned}
$$

\section{Demonstration:}

Let us write the recurrence equation corresponding to the definition of $V_{n}$ :

$$
V_{n-1}=\frac{V_{n}+G_{n}}{1+i}
$$


Equation (2b) can be rewritten as follows:

$$
\begin{aligned}
& V_{n-1}=\frac{V_{n}+G_{n}}{1+i_{n}}=\frac{V_{n}+F_{n}+\left[\left(1-t_{n}\right) r_{n}-\left(1-\theta_{n}\right) r_{n}^{\prime}\right] B_{n-1}}{1+w_{n} r_{n}\left(1-t_{n}\right)+\left(1-w_{n}\right) c_{n}} \\
& {\left[1+w_{n} r_{n}\left(1-t_{n}\right)+\left(1-w_{n}\right) c_{n}\right] V_{n-1}=V_{n}+F_{n}+\left[\left(1-t_{n}\right) r_{n}-\left(1-\theta_{n}\right) r_{n}^{\prime}\right] B_{n-1}}
\end{aligned}
$$

Replacing $B_{n-1}$ by $w_{n} V_{n-1}$ (debt ratio defined as a function of the theoretical value of the project), equation (4) becomes:

$$
V_{n-1}=\frac{V_{n}+F_{n}}{\left(1+w_{n} r_{n}^{\prime}\left(1-\theta_{n}\right)+\left(1-w_{n}\right) c_{n}\right)}=\frac{V_{n}+F_{n}}{1+y_{n}}
$$

This recurrence equation clearly corresponds to the proposed equation (2b).

\section{Use of the Arditti-Levy (BTWACC) method}

\subsection{Principles of the method}

Let us briefly recall the principle of this method that is commonly used in the exploration and production branch of the oil industry. It is based on the definition of a discount rate $s$ calculated as a Before Tax Weighted Average Cost of Capital. With the foregoing notations:

$s=w r+(1-w) c=i+w t r$

The cash flows considered $S_{n}$ can accordingly be defined as operating cash flows plus the interest tax shield. Hence:

$S_{n}=F_{n}+\theta_{n} r B_{n-1}$

(assuming here that the loan interest rate associated with the project is equal to the interest rate selected for all the loans of the company). If the project debt ratio is equal to the target debt ratio $w$, this method leads to the same decisions as the other standard methods (ATWACC, equity return, and in certain conditions - Pierru and Babusiaux [2000] - Adjusted Present Value of Myers).

More precisely, the Net Present Values, calculated by each of these methods, are equal if the project debt ratio, defined by reference to the theoretical economic value of the project, is equal to $w$ throughout the study period. In particular, if in year 0 , only the investment expenditures $I_{o}$ appear, this assumption implies that the capital amount borrowed in year 0 is (in section 1.3):

$$
B_{0}=w\left(I_{0}+N P V\right)
$$

The method can also be justified by examining a major project which receives specific financing that has no influence on the borrowing possibilities for the company's other projects (project 
financing, for example). In this case, the project can benefit from a different leverage than that of the company. The discount rate to be used is the average cost of financing associated with the project, and not the average cost of capital of the company.

\subsection{Project for which the debt ratio is different from the corporate debt ratio}

The loan amounts negotiated in practice to carry out an investment project are not necessarily in line with the target debt ratio, and the difference is sometimes significant. Let us examine such a project associated with a debt ratio $w^{\prime}$. We assume that the company wishes to respect a given target debt ratio $w$ throughout its financing, a commonly used assumption. Hence it is not possible to use the Arditti-Levy method without precaution, or directly use an equity return calculation.

Let us consider the example of a project which succeeds (or appears to succeed) in obtaining a loan $P^{\prime}$ corresponding to a fraction of the capital $w^{\prime}$ more than $w$. The use of the discount rate $s$ defined by using the target debt ratio $w$ is consistent with the assumption concerning the financing of the company ${ }^{2}$ s set of projects with the same class of risk.

But then we cannot calculate the cash flows $S_{n}$ by crediting the project with tax savings corresponding to the posting of the interest on loan $P^{\prime}$, in other words, calculated by reference to a ratio $w^{\prime}$ different from the ratio $w$ used to determine the discount rate. These tax credits would be higher than those produced by a loan satisfying the target debt ratio $w$. The difference would be an advantage which cannot (at least not entirely) be associated with the project, since with a fixed debt ratio $w$, the possibility that the project analyzed will have a ratio $w^{\prime}>w$ must be offset by a lower debt ratio on other projects.

To solve this problem, we propose to consider the loan $B_{n-1}^{\prime}$ as resulting from the addition of two different loans. We shall first limit the presentation to the case in which the interest rate on the loan associated with the project is not different from the one characterizing all the borrowings of the company.

- The first loan is defined as satisfying the target debt ratio $w$. Let $B_{n}$ be the corresponding capital amount not yet repaid in year $n$. The corresponding tax saving, to be credited to the project according to the Arditti-Levy formulation, is written in year $n$ :

$$
\theta_{n} r B_{n-1}
$$

- The second loan is obtained by difference. It is the one permitting the transition from debt ratio $w$ to debt ratio $w^{\prime}$. Let $C_{n}$ be the amount of the corresponding debt not yet repaid in year $n$. We therefore have:

$$
C_{n}=B_{n}^{\prime}-B_{n}
$$

If $w^{\prime}$ is higher than $w$, it is probably because the project is subject to a higher tax rate than the usual tax rate $t$, thereby permitting higher interest tax shields. This additional tax saving must be credited to the project, hence in year $n$ :

\footnotetext{
${ }^{2}$ Note also that the calculation of a weighted average is absolutely justified if the corporate debt ratio is assumed to be stable over the study period.
} 


$$
r\left(\theta_{n}-t\right) C_{n-1}
$$

(note that this formulation remains valid if $w^{\prime}<w, C_{n-1}$ having a negative sign).

\section{The total cash flow to be posted to the project is hence:}

$$
Z_{n}=F_{n}+\theta_{n} r B_{n-1}+\left(\theta_{n}-t\right) r C_{n-1}
$$

or: $Z_{n}=F_{n}+\theta_{n} r B_{n-1}^{\prime}-\operatorname{tr} C_{n-1}$

We shall now confirm that this process is consistent with the one proposed in the previous section for ATWACC calculations. We have considered a cash flow (for $r^{\prime}=r$ ):

$G_{n}=F_{n}+\left(\theta_{n}-t\right) r B_{n-1}^{\prime}$

hence:

$$
\begin{aligned}
& Z_{n}=G_{n}+\operatorname{tr} B_{n-1}^{\prime}-\operatorname{tr} C_{n-1} \\
& Z_{n}=G_{n}+\operatorname{tr} B_{n-1}
\end{aligned}
$$

The difference between the cash flows adapted to each method is equal to the tax saving relative to the interest associated with the first loan alone, a loan defined by reference to the company's target debt ratio $w$. This is clearly the case for which the consistency between the two methods has been demonstrated. The appendix offers a demonstration as well as the formulation of the approach proposed in the more general case in which the borrowing rates $r$ and $r^{\prime}$ are different.

\section{Reference tax rate and optimal allocation of debt}

In the foregoing discussion, we considered a project subject to a different tax rate from the one generally applied to the company. In an international oil company, not only one, but a large number of tax rates must be taken into account. How can rate $t$ be defined in this case? In theory, the company should assign the potential loans by increasing order of their after tax costs (for example, by permitting certain subsidiaries to contract proportionally more debt than others). The cost of the last loan used accordingly corresponds to the after tax marginal cost of the debt $\hat{r}_{m}$. It is the last loan to serve as a reference in defining the loan $\pi$ to be substituted by the borrowing $P^{\prime}$ associated with a project under examination. It is in relation to this marginal cost $\hat{r}_{m}$ (if it can be determined by the central services of the company) that the gain $\left(\hat{r}_{m}-\hat{r}^{\prime}\right) B_{n-1}^{\prime}$ to be credited to the project must be calculated.

Maximizing the value of the project or that of the company clearly leads to the same decision: a loan will only be allocated to the project if $\hat{r}_{m}-\hat{r}^{\prime} \geq 0$, i.e. if the after tax cost of the loan is advantageous (reflected by a positive cash flow). If not, allocating a loan to a project decreases the Net Present Value of this project. Since the point of view of the project and that of the company are consistent, the financing decision can thus theoretically be decentralized. 


\section{Conclusions and discussion}

The first part of this article showed that ATWACC calculations can be adjusted very simply to account for special tax rates specific to an investment project, and particularly the sometimes complex tax rates in force in oil and gas Exploration and Production. Note moreover that the formulation selected is independent of the loan share in financing the project and of considerations pertaining to the corporate debt ratio.

As to the Arditti-Levy method, it is routinely used for analyzing projects in ExplorationProduction. Yet its application demands a number of precautions, well known to the specialists, but which make decentralization of the decisions sometimes difficult. In fact, it is not sufficient to give the value of the discount rate to the different managers. The first verification to be made is naturally to check the compatibility between the financing assumptions selected for determining the discount rate and those made to calculate the financing costs and corresponding tax savings. In practice, the use of the method, in its original version, is clearly limited in principle to the analysis of projects featuring financing by borrowing consistent with the debt ratio targets set by the company. Even in this case, the non-specialist may encounter a number of problems. Here are some of them:

Sensitivity to loan interest rate: The project internal rate of return, all other things remaining equal, is commensurately higher as the interest rate rises. This may surprise the inexperienced analyst who plans to use an unchanged discount rate.

Loan repayment period: The loan repayment period may be significantly shorter than the life of the project. This corresponds to a situation quite distant from the assumption of a constant debt ratio over the study period, and may sometimes lead to an underestimation of the project's profitability.

Economic value of a project: Let us consider a project for the carrying out of which the capital borrowed represents a fraction of the investment equal to the target debt ratio $w$, hence: $B_{0}=w I_{0}$. In this case, the NPV calculated ${ }^{3}$ with the ATWACC method and the Arditti-Levy method (and the equity residual method) are in principle of the same sign but with distinct values ${ }^{4}$. If the aim is to analyze a decision to approve or reject the project, both (or all three) methods lead to the same proposal. But to define the price that the company can accept to buy or sell a share in the project, it is the economic value of the project $\left(V_{n}\right.$ in year $\left.n\right)$ which must serve as the reference. Finding different values with different methods could be a problem.

Now let us return to the study of projects featuring a debt ratio $w^{\prime}$ different from the corporate ratio $w$. An appropriate formulation was proposed in section 2.2. But this formulation, while not complex, does not have the simplicity of the one presented in the first part. In summary, the generalized ATWACC method does not have the same drawbacks as the Arditti-Levy method. It has moreover an advantage. In the most common cases outside the exploration and production sector, the fiscal system applied to the revenues of the project is not different from that which applies to the company. The proposed method then reverts to the classic ATWACC method. Its use would allow one to have the same criterion for all the various activities of an oil company (the use of this criterion would besides be more line with the general practice of the industrial

\footnotetext{
${ }^{3}$ Equations between the NPV obtained in this case by the different methods are given in Babusiaux [1990]

${ }^{4}$ In fact they are equal if $B_{0}=w\left(I_{0}+N P V\right)$
} 
world than that of Arditti-Levy). In the present state of our knowledge, and while awaiting the response of the industry specialists, the generalization of the ATWACC method hence appears to us preferable to that of the Arditti-Levy method. 


\section{References}

Babusiaux, Denis, 1990, Décision d'investissement et calcul économique dans l'entreprise (Ed. Economica, Ed. Technip, Paris).

Boudreaux, Kenneth J., and Hugh W. Long, 1979, The weighted average cost of capital as a cutoff rate: a further analysis, Financial Management 8, Summer, 7-14.

Chambers, Donald R., Robert S. Harris, and John J. Pringle, 1982, Treatment of financing mix in analyzing investment opportunities, Financial Management 8, Summer, 24-41.

Linke, Charles M., and Moon K. Kim, 1974, More on the weighted average cost of capital: a comment and analysis, Journal of Financial and Quantitative Analysis 9, 1069-1080.

Pierru, Axel, and Denis Babusiaux, 2000, A general approach to different concepts of cost of capital; in Bonilla, M., Casasus, T., Sala, R., eds.: Financial Modelling (Springer Verlag, contributions to Management Science), 339-351. 


\section{$\underline{\text { Appendix }}$}

Consistency of the ATWACC method with the Arditti-Levy (BTWACC) method

The demonstration presented here generalizes those put forward by Boudreaux and Long (1979) and Babusiaux (1990). In fact:

- any loan interest rate may be allocated to the project,

- the project debt ratio may be different from the corporate target ratio,

- the project tax rate $\theta_{n}$ may be different in each year $n$.

Let us resume the notations employed in sections 1.2 and 2.2, in particular:

After tax cost of the debt allocated to the project: $\hat{r}_{n}^{\prime}=\left(1-\theta_{n}\right) r^{\prime}$

After tax cost of the loan used to calculate the discount rate: $\hat{r}=(1-t) r$

Cash flows $G_{n}$ and $Z_{n}$ to be taken into account respectively with the ATWACC method and the Arditti-Levy method are the following (each year $n$ ):

$$
\begin{aligned}
& G_{n}=F_{n}+\left(\hat{r}-\hat{r}_{n}^{\prime}\right) B_{n-1}^{\prime} \\
& Z_{n}=F_{n}+\left(r-\hat{r}_{n}^{\prime}\right) B_{n-1}+\left(\hat{r}-\hat{r}_{n}^{\prime}\right) C_{n-1}
\end{aligned}
$$

Note that this definition of $Z_{n}$ generalizes to the case $r^{\prime} \neq r$ the one given in section 2.2.

Since $B_{n-1}^{\prime}=B_{n-1}+C_{n-1}$, we hence have: $Z_{n}=G_{n}+\operatorname{tr} B_{n-1}$

This gives us an equation similar to the one relating the cash flows $F_{n}$ and $S_{n}$ associated with the two methods in their original definition:

$$
S_{n}=F_{n}+\operatorname{tr} B_{n-1}
$$

\section{1 - Equality of net present values}

The demonstration is made by recurrence:

let $\quad V_{n}=\sum_{k=n+1}^{N} \frac{G_{k}}{(1+i)^{k-n}} \quad$ and $\quad W_{n}=\sum_{k=n+1}^{N} \frac{Z_{k}}{(1+s)^{k-n}}$

We shall show that $W_{n}=V_{n}$ each year $n$.

We evidently have $W_{N}=V_{N}=0$.

Let us assume that $W_{n}=V_{n}$ and show that hence $W_{n-1}=V_{n-1}$. 
By definition, we have: $W_{n-1}=\frac{Z_{n}+W_{n}}{1+s}$

Replacing $W_{n}$ by $V_{n}, Z_{n}$ by $G_{n}+\operatorname{tr} B_{n-1}$ and $B_{n-1}$ by $w W_{n-1}$ ( $B_{n-1}$ has been defined as the share of borrowing satisfying the target debt ratio $w$ ) and by noting that $i=s-t r w$ we obtain:

$$
W_{n-1}=\frac{G_{n}+V_{n}}{1+i}
$$

We therefore have $W_{n-1}=V_{n-1}$.

In particular, we have $W_{0}-I_{0}=V_{0}-I_{0}$, so that both methods yield the same net present value.

\section{2 - Consistency of methods when using Internal Rates of Return}

The result derived above is sufficient to prove that the use of Internal Rates of Return leads to the same decision as NPVs calculations. Nevertheless, it is possible to cast a new light on the consistency of both methods without the use of the discount rate (necessary to determine the economic value of the project). For this, we will introduce another definition for a debt ratio and thus for the loan satisfying the target debt ratio $w$.

We will present the formulation in the case where cash-outflows in year 0 are only investment outlays (noted $I_{0}$ ) (the generalization, allowing us to release this assumption, is immediate).

Let us consider the amount invested ( $I_{0}$ in year 0 ) as a loan made by the financial department of the firm to the department in charge of the project (whatever be the origin of these funds). This loan is reimbursed with the cash inflows of the project (flows $G_{n}$ when they are positive). Its interest rate is equal to the Internal Rate of Return of the project, noted $r_{g}$, which implies that the loan will be entirely reimbursed at the end of the study period without any gain or loss for the department in charge of the project.

Let us note $K_{n}$ the capital not yet reimbursed (to the financial department) at the end of year $n$ $K_{n}$ is defined according to the following recursion relationship :

$$
\begin{aligned}
& K_{n}=\left(1+r_{g}\right) K_{n-1}-G_{n} \\
& K_{0}=I_{0} \\
& K_{N}=0
\end{aligned}
$$

We will now introduce the (fictitious) loan defined as satisfying the target debt ratio $w$.

Let us note $\bar{B}_{n}$ the amount of this loan not yet reimbursed at the end of the year $n$. The amount $\bar{B}_{0}$ borrowed in year 0 is defined as following :

$$
\bar{B}_{0}=w I_{0}
$$


Expressed in other terms, the debt ratio to be satisfied in year 0 is a ratio defined in reference to the investment outlay and not, as in the preceding paragraph, to the economic value of the project. For any given year, the reimbursement will be scheduled such that :

$$
\bar{B}_{n}=w K_{n}
$$

The debt ratio corresponding to this fictitious loan is thus defined with reference to the total amount not yet reimbursed (by the department in charge of the project) to the financial department (the debt ratio $w$ is thus defined in the sense of Linke and Kim [1974]).

The cash flows to be used with the Arditti-Levy method can be defined in a way similar to that of $\S 2.2$, by replacing $B_{n}$ with $\bar{B}_{n}$ and $C_{n}$ with $\bar{C}_{n}$

$$
\bar{C}_{n}=B_{n}^{\prime}-\bar{B}_{n}
$$

The cash flow to be associated to the project is then written :

$$
\begin{aligned}
& \bar{Z}_{n}=F_{n}+\theta_{n} r \bar{B}_{n-1}+\left(\theta_{n}-t\right) r \bar{C}_{n-1} \\
& \bar{Z}_{n}=G_{n}+t r \bar{B}_{n-1}
\end{aligned}
$$

By combining equations $\mathrm{A} 1$ and $\mathrm{A} 2$ and replacing $\bar{B}_{n-1}$ with $w K_{n-1}$, we obtain :

$$
K_{n}=\left(1+r_{g}+w r t\right) K_{n-1}-\bar{Z}_{n}
$$

id est:

$$
K_{0}=\sum_{k=1}^{N} \frac{G_{k}}{\left(1+r_{g}\right)^{k}}=\sum_{k=1}^{N} \frac{\bar{Z}_{k}}{\left(1+r_{g}+w r t\right)^{k}}=I_{0}
$$

The internal rate of return obtained with the Arditti-Levy method is:

$$
r_{s}=r_{g}+w r t
$$

If we compare this relationship to the one linking the discount rates of both methods :

$$
s=i+w r t
$$

we observe that

$$
r_{s} \geq s
$$

if and only if : 
$r_{g} \geq i$

Both methods lead to the same decision.

N.B. : The two lights cast on methods consistency, one involving net present values and the other internal rates of return, are both based on an identical definition of the fictitious loan (satisfying the debt ratio $w$ ) when studying a marginal project (with NPV=0). 


\section{Déjà parus}

CEG-1. D. PERRUCHET, J.-P. CUEILLE,

Compagnies pétrolières internationales : intégration verticale et niveau de risque.

Novembre 1990

CEG-2. C. BARRET, P. CHOLLET,

Canadian gas exports: modeling a market in disequilibrium.

Juin 1990

CEG-3. J.-P. FAVENNEC, V. PREVOT,

Raffinage et environnement.

Janvier 1991

\section{CEG-4. D. BABUSIAUX,}

Note sur le choix des investissements en présence de rationnement du capital.

Janvier 1990

\section{CEG-5. J.-L. KARNIK,}

Les résultats financiers des sociétés de raffinage distribution en France 1978-89.

Mars 1991

\section{CEG-6. I. CADORET, P. RENOU,}

Élasticités et substitutions énergétiques : difficultés méthodologiques.

Avril 1991

\section{CEG-7. I. CADORET, J.-L. KARNIK,}

Modélisation de la demande de gaz naturel dans le secteur domestique : France, Italie, Royaume-Uni 1978-1989. Juillet 1991

\section{CEG-8. J.-M. BREUIL,}

Émissions de $\mathrm{SO} 2$ dans l'industrie française : une approche technico-économique.

Septembre 1991

CEG-9. A. FAUVEAU, P. CHOLLET, F. LANTZ,

Changements structurels dans un modèle économétrique de demande de carburant.

Octobre 1991

CEG-10. P. RENOU,

Modélisation des substitutions énergétiques dans les pays de l'OCDE.

Décembre 1991

CEG-11. E. DELAFOSSE,

Marchés gaziers du Sud-Est asiatique : évolutions et enseignements.

Juin 1992

\section{CEG-12. F. LANTZ, C. IOANNIDIS,}

Analysis of the French gasoline market since the deregulation of prices.

Juillet 1992

\section{CEG-13. K. FAID,}

Analysis of the American oil futures market.

Décembre 1992

\section{CEG-14. S. NACHET,}

La réglementation internationale pour la prévention et l'indemnisation des pollutions maritimes par les hydrocarbures.

Mars 1993 
CEG-15. J.-L. KARNIK, R. BAKER, D. PERRUCHET,

Les compagnies pétrolières : 1973-1993, vingt ans après.

Juillet 1993

\section{CEG-16. N. ALBA-SAUNAL,}

Environnement et élasticités de substitution dans l'industrie ; méthodes et interrogations pour l'avenir.

Septembre 1993

\section{CEG-17. E. DELAFOSSE,}

Pays en développement et enjeux gaziers : prendre en compte les contraintes d'accès aux ressources locales.

Octobre 1993

\section{CEG-18. J.P. FAVENNEC, D. BABUSIAUX*,}

L'industrie du raffinage dans le Golfe arabe, en Asie et en Europe : comparaison et interdépendance.

Octobre 1993

\section{CEG-19. S. FURLAN,}

L'apport de la théorie économique à la définition d'externalité.

Juin 1994

\section{CEG-20. M. CADREN,}

Analyse économétrique de l'intégration européenne des produits pétroliers : le marché du diesel en Allemagne et en France.

Novembre 1994

\section{CEG-21. J.L. KARNIK, J. MASSERON*,}

L'impact du progrès technique sur l'industrie du pétrole.

Janvier 1995

CEG-22. J.P. FAVENNEC, D. BABUSIAUX,

L'avenir de l'industrie du raffinage.

Janvier 1995

CEG- 23. D. BABUSIAUX, S. YAFIL*,

Relations entre taux de rentabilité interne et taux de rendement comptable.

Mai 1995

CEG-24. D. BABUSIAUX, J. JAYLET*,

Calculs de rentabilité et mode de financement des investissements, vers une nouvelle méthode ? Juin 1996

CEG-25. J.P. CUEILLE, J. MASSERON*,

Coûts de production des énergies fossiles : situation actuelle et perspectives.

Juillet 1996

\section{CEG-26. J.P. CUEILLE, E. JOURDAIN,}

Réductions des externalités : impacts du progrès technique et de l'amélioration de l'efficacité énergétique. Janvier 1997

\section{CEG-27. J.P. CUEILLE, E. DOS SANTOS,}

Approche évolutionniste de la compétitivité des activités amont de la filière pétrolière dans une perspective de long terme.

Février 1997

\section{CEG-28. C. BAUDOUIN, J.P. FAVENNEC,}

Marges et perspectives du raffinage.

Avril 1997 
CEG-29. P. COUSSY, S. FURLAN, E. JOURDAIN, G. LANDRIEU, J.V. SPADARO, A. RABL,

Tentative d'évaluation monétaire des coûts externes liés à la pollution automobile : difficultés méthodologiques et étude de cas.

Février 1998

\section{CEG-30. J.P. INDJEHAGOPIAN, F. LANTZ, V. SIMON,}

Dynamique des prix sur le marché des fiouls domestiques en Europe.

Octobre 1998

CEG-31. A. PIERRU, A. MAURO

Actions et obligations : des options qui s'ignorent.

Janvier 1999

CEG-32. V. LEPEZ, G. MANDONNET

Problèmes de robustesse dans l'estimation des réserves ultimes de pétrole conventionnel.

Mars 1999

CEG-33. J. P. FAVENNEC, P. COPINSCHI

L'amont pétrolier en Afrique de l'Ouest, état des lieux

Octobre 1999

CEG-34. D. BABUSIAUX

Mondialisation et formes de concurrence sur les grands marchés de matières premières énergétiques : le pétrole. Novembre 1999

\section{CEG-35. D. RILEY}

The Euro

Février 2000

\footnotetext{
* une version anglaise de cet article est disponible sur demande
} 